\title{
Flaming Dormant Alfalfa for Pest Control
}

\author{
Joseph L. Moyer ${ }^{1}$, R. J. Whitworth ${ }^{2}$, H. Davis ${ }^{2}$ \\ ${ }^{1}$ Southeast Agricultural Research Center, Kansas State University, Parsons, USA \\ ${ }^{2}$ Department of Entomology, Kansas State University, Manhattan, USA \\ Email: "imover@ksu.edu
}

Received 22 January 2014; revised 23 February 2014; accepted 4 March 2014

Copyright (C) 2014 by authors and Scientific Research Publishing Inc.

This work is licensed under the Creative Commons Attribution International License (CC BY).

http://creativecommons.org/licenses/by/4.0/

(c) (i) Open Access

\begin{abstract}
Alfalfa (Medicago sativa Leyss) is an important forage crop whose production is hampered by pests, including the alfalfa weevil (Hypera postica Gyllenhal) which is a major problem in many areas. Flaming during dormancy could be an alternative control measure. Late fall and early spring flaming at three intensities were compared with pesticide and no treatment for their effects on alfalfa weevil damage and weed density. In four site-years, flaming at high intensity generally reduced weevil damage to alfalfa. When winter annual broadleaf weeds were prevalent, flaming decreased their density. When fall and spring flaming effects were different, spring flaming gave better results.
\end{abstract}

\section{Keywords}

Weevil; Hypera; Weed Control; Burning

\section{Introduction}

Alfalfa (Medicago sativa Leyss) is a major forage crop fed primarily to dairy cows and other livestock that require high-quality feed. Alfalfa has produced the highest average net returns of dryland crops in Kansas, even for the "post-ethanol" years of 2007 to 2012, and is rivaled only by soybean [1]. In the previous five years (2008 to 2012), an average of 8 million hectares of alfalfa were harvested in the US, producing more than 59 million tons of dry hay valued more than $\$ 9.5$ billion [2]. Alfalfa is also one of the more prolific nitrogen-fixing legumes, making it useful in long-term rotations as a soil-builder that can supply nitrogen to ensuing crops. Thus, despite a recent decline in area, it maintains its place as the fourth-ranked harvested and valued crop in the U.S.

Alfalfa production continues to be hampered by numerous pests, particularly the alfalfa weevil (Hypera postica Gyllenhal) [3]. The weevil causes substantial costs to producers in many regions in terms of both forage yield and

"Corresponding author. 
feeding value. Alfalfa weevil larvae affects quality by attacking the upper canopy with its emerging leaf buds, which removes emerging leaflet mesophyll that contains the leaf fractions with the highest concentrations of crude protein and soluble nutrients, leaving behind less digestible fibrous components and reducing overall digestibility. Defoliation of early spring growth also damages the alfalfa plant because it further depletes reserve energy that initiated spring growth and reduces prime photosynthetic area that is needed to replenish reserves for regrowth after the first cutting, which can result in reduced stand life.

Plant breeders have attempted to find sources of weevil resistance using glandular-haired genotypes that discourage proliferation of some insects by physically impairing oviposition, but this approach has not been sufficient to control alfalfa weevil [4]. The introduction of recombinant gene(s) for weevil resistance into alfalfa has been demonstrated [5], but many have not accepted the use of genetically engineered crops, and such crops are unacceptable for organic production.

Biological control agents for alfalfa pests have been introduced and developed [6]. At least six parasitoid species have been introduced and help maintain alfalfa weevil populations below damaging levels in the northeastern US. In Virginia, however, alfalfa weevil numbers often exceed established economic thresholds due to environmental and biological interactions [7]. Some biological agents may not survive in all alfalfa-growing areas [8], and these agents often lag behind pest numbers, allowing significant buildup and subsequent damage before the control population can respond. Recent reports of weevil numbers and damage indicate that biological controls are often inadequate for preventing damage in many of the US alfalfa-growing areas [9].

Insecticides are often the most economically feasible control option, but they often disrupt natural controls of the weevil, enabling secondary pest outbreaks [10]. Insecticides are also prohibited for certified organic production. The weevil management option practiced by many organic alfalfa producers is in early cutting when larvae numbers reach a critical threshold. If the major larval damage occurs after sufficient alfalfa growth has occurred, this is a feasible alternative. In South Dakota, harvesting two to three weeks early (after bud stage) resulted in nonsignificant $(\mathrm{P}>0.05)$ yield reductions in four of six location-years, producing an average loss of only 5\% and an average increase in forage crude protein of 1.9 percentage points, but yield losses near $20 \%$ were sustained in two location-years [11]. Larval numbers in some seasons may reach damaging levels before forage production is sufficient to justify cutting, and if this occurs before plant reserves are adequately replenished, subsequent cuttings and even stand persistence can be affected.

Much alfalfa weevil damage occurs in the first cutting, which is often the most productive. First-generation larvae from eggs laid in stem bases during fall and open periods of winter and early spring cause most of this damage. The eggs hatch when they receive adequate heat units [12], sometime after alfalfa growth has begun.

Removal of fall alfalfa residue could reduce the larval population from the earliest hatches, thus delaying the economic threshold for spraying until the first cutting can be taken. One alternative is to cut after fall dormancy, but in Kansas, early spring growth can occur, which enables overwintering adults to continue egg-laying, thus prolonging the hatching period prior to the first cutting. For example, in southeastern Kansas, alfalfa was harvested in late November in 1990 and 1991, but fall cutting affected neither subsequent first-cut yields, weevil larvae number, nor alfalfa tip damage. Alfalfa stubble removal in early February by flailing to $<4 \mathrm{~cm}$, however, increased first-cut yield by $10 \%$ and 60\% in 1991 and 1992, respectively [13]. In Oklahoma, peak alfalfa weevil numbers were not lower due to mid-November cutting compared with no cutting after September, nor were first-cut alfalfa yields increased by the late-fall cutting [14] [15]. Removing fall residue on 12 February in Manhattan, Kansas, reduced peak weevil numbers two weeks before the first cutting by $45 \%$ and increased first-cut yield by $50 \%$ [16].

Removal of residual fall growth by grazing animals in fall and winter has been tested and recommended. In a five-year Oklahoma study, alfalfa plots were grazed for two to three weeks during December and January with 12 to 15 head of cattle per ha, and had alfalfa weevil numbers reduced by an average of 25\% [14]. However, first-cut alfalfa yield was affected only in two years, one positively and one negatively, and final alfalfa plant numbers were similar for grazed, fall-cut, and uncut plots [15]. In New Zealand, winter sheep treading for one week reduced spring numbers of blue-green aphid (Acyrthosiphon kondoi), and two weeks of treading reduced spring larval numbers of the weevil Sitonia discoideus [17]. Over the four-year period, first-cut yields were not affected until treading occurred for four weeks, and plant numbers were not affected by treatment.

Flaming or burning alfalfa residue during dormancy has been listed as a pest control alternative for decades [6] [18]. A pure stand of dormant alfalfa will not sustain combustion, so flaming with an external combustible material is necessary. In the study cited earlier [13], flaming with propane in February rather than removing with a 
flail-type mower increased first-cut yields over the check by 16\% and 96\% in 1991 and 1992, respectively.

Dormant-season flaming could also affect other pests such as aphids and/or other insects and diseases. The use of flaming for weed control was recently reviewed [19], but the study considered only annual crops that had been treated during the growing season. The authors identified advantages for flaming that could apply to alfalfa production; i.e., there were no residual crop or environmental effects from chemicals, and one flaming treatment could replace separate treatments and spare the expense for insecticide and herbicide. In comparing flaming of 11 weed species, however, the authors found that higher amounts of fuel were required to control broadleaf versus grassy weeds at similar stages [19]. In an alfalfa study, early spring flaming did not reduce downy bromegrass (Bromus tectorum L.) production in the first cutting, whereas broadleaf weed production was reduced by $75 \%[13]$.

The objective of this study was to compare late-fall and early spring residue removal by flaming at different intensities using an LP gas burner with chemical control treatments for effects on weevil damage, weed density, forage production, and presence of other pests. The first criterion for evaluation was efficacy, as measured by reduction in populations of weevil larvae, and other pests such as aphids and weeds, and ultimately in terms of pure alfalfa yield and quality.

\section{Materials and Methods}

\subsection{Year 1: 2011-2012}

In Labette County, KS, near Mound Valley, plots were located in an established > 5-year alfalfa stand. In Lyon County, KS, plots were also in an established field. Treatments at both sites included a $3 \times 2$ factorial of flaming treatments, applied at one of two times, "fall" or "spring," at one of three intensities of flaming, varied by the speed of the burner. A positive, pesticide-treated check and an untreated (negative) check were included to comprise eight treatments. Four replications were arranged in a randomized complete block design with individual plots of $3 \times 7.5 \mathrm{~m}$.

The burners were Flame Engineering Model LT $2 \times 8$, built as described in [20]. They were spaced at $30 \mathrm{~cm}$ and operated at $350 \mathrm{kPa}$ with burner tips $5-8 \mathrm{~cm}$ above the ground.

Fall flaming was performed at Mound Valley on 29 November and at Emporia on 15 November. Spring flaming occurred on 27 February at Mound Valley and 6 March at Emporia. Plots were flamed at $3.4 \mathrm{~km} / \mathrm{hour}$ for "low", $2.1 \mathrm{~km} / \mathrm{hour}$ for "medium", and $1.8 \mathrm{~km} /$ hour for "high" intensity. Although all intensities removed dry residue, temperatures at the soil surface varied with intensity, influenced by atmospheric and canopy conditions. At Mound Valley on 29 November, with air temperature of $2^{\circ} \mathrm{C}$ and still conditions, temperatures at the soil surface measured about $10^{\circ} \mathrm{C}, 55^{\circ} \mathrm{C}$, and $91^{\circ} \mathrm{C}$ for low, medium, and high intensity, respectively, measured with an Omega Type $\mathrm{K}$ high-temperature probe. Soil surface temperatures at Emporia were similar for the fall flaming, despite warmer air temperature, because wind velocity was low at both locations. In spring, air temperature at Emporia on 6 March reached above $16^{\circ} \mathrm{C}$, but the wind velocity was $50 \mathrm{~km} /$ hour with gusts to 55 or greater, so soil surface temperature from the Low-intensity flaming was ca. $25^{\circ} \mathrm{C}$, but temperatures at the higher intensities could rarely exceed $38^{\circ} \mathrm{C}$.

The pesticide-treated check received a dormant herbicide application of $2.8 \mathrm{~kg} / \mathrm{ha}$ of AlfaMax $^{\circledR}$ (54\% diuron and $46 \%$ hexazinone) on 4 January at Mound Valley and 6 March at Emporia. Pesticide-treated plots also received $0.84 \mathrm{~kg} / \mathrm{ha}$ ai of chlorpyrifos on 28 March at both locations, although all plots at Emporia had been inadvertently sprayed with insecticide by the cooperator about two weeks earlier due to early weevil emergence.

Air temperatures in early 2012 were warmer than usual in eastern Kansas. The NOAA weather station at the Mound Valley Unit of the Southeast Agricultural Research Center ca. $4 \mathrm{~km}$ south of the plot area recorded mean air temperatures for January, February, and March 2012 that were $3.0^{\circ} \mathrm{C}, 1.7^{\circ} \mathrm{C}$, and $5.5^{\circ} \mathrm{C}$, respectively, above the 30-year average. These temperatures provided the heat units required for hatching [12] one to two weeks earlier than average, leading to a prolonged period of infestation that was dealt with by many producers with multiple insecticide applications.

Plots at both locations were evaluated visually for alfalfa weevil damage on a scale of 0 to 5 , based on percentage of leaves damaged, and similarly for assessment of weed density. This occurred on 28 March at Emporia and 3 April at Mound Valley. Plots at Mound Valley were cut with a flail-type plot harvester on 23 May for determination of forage production and subsampled for total forage dry matter and $\mathrm{N}$ concentrations. No further data were collected at Emporia because all plots were again sprayed with insecticide in early April. 
Subsamples of pure weed and alfalfa were collected at harvest from the Mound Valley site from each replication and assayed, as was a total forage subsample from each plot. Dry matter and N contents of weed and alfalfa varied enough to calculate proportion of alfalfa in samples of each plot, using the method of Cooper et al. [21] (see Table 1). The formula used was

$$
A=\left(N_{s}-N_{w}\right) /\left(N_{a}-N_{w}\right)
$$

where $A$ = proportion of alfalfa in mixture, $N_{s}=N$ concentration in the subsample on a fresh weight basis, $\mathrm{N}_{\mathrm{w}}=$ $\mathrm{N}$ concentration of weeds on a fresh basis, and $\mathrm{N}_{\mathrm{a}}=\mathrm{N}$ concentration of alfalfa on a fresh basis.

Data were analyzed using PROC ANOVA of the Statistical Analysis System [22] using Fisher's protected LSD for multiple comparisons. Relationships among variables were evaluated with Pearson correlation coefficients obtained using PROC CORR.

\subsection{Year 2: 2012-2013}

Two sets of plots were located in Labette County, KS, including the same plots that were used the previous year. The other set was located near Dennis, KS, using the same experimental design. Fall flaming was performed 12 December and spring flaming was 13 March at both locations. Speeds were similar for the previous low- and medium-intensity flaming, 3.5 and $2.1 \mathrm{~km} /$ hour, respectively. For high intensity, however, the speed was reduced to $1.1 \mathrm{~km} /$ hour for increased temperature at that treatment. Temperatures at the soil surface for the fall flaming were about $47^{\circ} \mathrm{C}, 54^{\circ} \mathrm{C}$, and $98^{\circ} \mathrm{C}$ for low, medium, and high flaming intensities, respectively, when air temperature was approaching a high of $10^{\circ} \mathrm{C}$. On $13 \mathrm{March}$, when air temperature was near the $26^{\circ} \mathrm{C}$ daily maximum, soil surface temperatures reached $69^{\circ} \mathrm{C}, 84^{\circ} \mathrm{C}$, and $129^{\circ} \mathrm{C}$ for low, medium, and high flaming intensities, respectively.

The positive (pesticide-treated) check plots at Dennis were sprayed for weed control on 20 March with 1.1 $\mathrm{kg} / \mathrm{ha}$ ai of 2,4-DB and $0.34 \mathrm{~kg} / \mathrm{ha}$ ai of sethoxydim, with $0.5 \%$ non-ionic surfactant. Positive checks at Dennis were sprayed on 9 April for weevil control with $0.14 \mathrm{~kg} / \mathrm{ha}$ of Baythroid XL insecticide. At Mound Valley, the

Table 1. Effect of alfalfa treatments in 2011-2012 on subsequent weevil damage and weed density on 3 April, and total and alfalfa forage production on 23 May, 2012, Steve Black Farm, Mound Valley, KS.

\begin{tabular}{|c|c|c|c|c|c|}
\hline \multicolumn{2}{|c|}{ Flaming treatment } & \multirow{2}{*}{$\begin{array}{c}\text { Weevil } \\
\text { damage }^{3}\end{array}$} & \multirow{2}{*}{$\begin{array}{l}\text { Weed } \\
\text { density }^{4}\end{array}$} & \multirow{2}{*}{$\begin{array}{c}\text { Total forage } \\
\text { yield }\end{array}$} & \multirow{2}{*}{$\begin{array}{l}\text { Alfalfa } \\
\text { yield }^{6}\end{array}$} \\
\hline Timing $^{1}$ & Intensity $^{2}$ & & & & \\
\hline & & \multicolumn{2}{|c|}{0 to 5} & \multicolumn{2}{|c|}{$\mathrm{Mg} / \mathrm{ha}^{5}$} \\
\hline \multirow[t]{3}{*}{ Fall } & Low & 3.8 & 3.8 & 3.20 & 1.26 \\
\hline & Medium & 3.1 & 2.3 & 3.26 & 2.39 \\
\hline & High & 2.7 & 2.0 & 3.32 & 1.96 \\
\hline \multirow[t]{3}{*}{ Spring } & Low & 2.7 & 3.7 & 3.38 & 1.78 \\
\hline & Medium & 3.8 & 3.4 & 3.04 & 2.13 \\
\hline & High & 2.8 & 2.0 & 3.36 & 2.61 \\
\hline \multicolumn{2}{|c|}{ Spring pesticides ${ }^{7}$} & 1.8 & 0.0 & 2.67 & 2.67 \\
\hline \multicolumn{2}{|c|}{ No treatment } & 4.1 & 3.9 & 3.00 & 3.00 \\
\hline & $\operatorname{LSD}_{(0.05)}$ & 1.2 & 1.2 & 0.53 & 1.01 \\
\hline \multicolumn{6}{|c|}{ Means, flaming treatment } \\
\hline Fall & & 3.2 & 2.7 & 3.26 & 1.17 \\
\hline Spring & & 3.1 & 3.0 & 3.26 & 1.24 \\
\hline \multirow[t]{5}{*}{$\operatorname{LSD}_{(0.05)}$} & & NS & NS & NS & NS \\
\hline & Low & 3.2 & 3.7 & 3.28 & 1.52 \\
\hline & Medium & 3.4 & 2.8 & 3.14 & 2.25 \\
\hline & High & 2.7 & 2.0 & 3.34 & 2.29 \\
\hline & $\operatorname{LSD}_{(0.05)}$ & NS & 1.0 & NS & NS \\
\hline
\end{tabular}

${ }^{1}$ Fall flaming, 29 November 2011; spring flaming, 27 February 2012. ${ }^{2}$ Intensities: low $=2.11 \mathrm{mph}$; medium = $1.25 \mathrm{~m}$. p.h; high $=1.14 \mathrm{~m} . \mathrm{p} . \mathrm{h} .{ }^{3} \mathrm{Visual}$ rating: $0=$ none, 5 = all leaves damaged. ${ }^{4}$ Rating: $0=$ no weeds, $5=$ weed coverage over entire plot. ${ }^{5}$ Yield expressed as megagrams DM/hectare. ${ }^{6}$ Calculated by replication from concentrations in pure alfalfa and weeds (see Methods). Average DM and N were 282 and $27.2 \mathrm{~g} / \mathrm{kg}$ for alfalfa, and 384 and 19.3 for weeds. ${ }^{7}$ Sprayed with AlfaMax ${ }^{\circledR}$ on 4 January 2012; with Lorsban ${ }^{\circledR}$ on 28 March. 
positive control was sprayed on 9 April with $0.49 \mathrm{~kg} / \mathrm{ha}$ ai chlorpyrifos and $0.11 \mathrm{~kg} / \mathrm{ha}$ zeta-cypermethrin for weevil control, then with $0.84 \mathrm{~kg} / \mathrm{ha}$ ai glyphosate and $0.5 \%$ non-ionic surfactant for weed control, because it was a Roundup-Ready variety.

Plots at Mound Valley were evaluated visually for percentage of alfalfa leaves damaged by weevils (Table 1) on 9 April and 17 April, and counts of weevil larvae per 10 stems were taken on the latter date. Alfalfa was harvested for forage yield and subsampled for dry matter content on 13 May; weed infestation was relatively minor. At Dennis, weevils appeared later, and weed infestation differences made visual assessment difficult, so plots were harvested on 11 May for forage yield and subsampled for dry matter, $\mathrm{N}$, and P contents. Subsamples of pure weed and alfalfa were collected as before to determine alfalfa percentage in forage. Dry matter, N, and P contents of weed and alfalfa varied enough to calculate the percentage of alfalfa in plot samples as before [21], except that N/P ratios (on a fresh weight basis) were used.

\section{Results and Discussion}

\subsection{Year 1: 2011-2012}

At Mound Valley, weevil damage on 3 April was greater with the negative check (no treatment) than with pesticide treatment (positive check), high-intensity fall flaming, or spring flaming at low or high intensity (Table 1). In the absence of an interaction between time and intensity of flaming, average weevil damage with fall or spring flaming did not differ. Flaming intensity had no significant effect, although the high-intensity treatments appeared to show less weevil damage.

A moderate infestation of cool-season annual broadleaf weeds occurred, primarily of shepherdspurse [Capsella bursa-pastoris (L.) Medik] and henbit (Lamium amplexicaule L.). Weed density was lower where pesticide was used than in all other treatments (Table 1). Density was higher with no treatment than with fall flaming at medium and high intensity and with spring flaming at high intensity. Average weed density was less with highthan low-intensity flaming, with the medium intensity treatment intermediate. Average weed density did not differ in average weed density between fall and spring flaming.

Total forage yield on 23 May was lower from the pesticide treatment than from all flamed treatments except for the spring-flamed at medium intensity, similar to the untreated check (Table 1). This was because of the difference in weed yield of the treatments, as indicated by the difference in total forage and alfalfa yield from different treatments. Because AlfaMax-treated plots were virtually weed-free, the yield of pure alfalfa was calculated to be higher for the pesticide and high-intensity spring flaming treatments than for the untreated and low-intensity fall flaming treatments. The relationship between the weed density assessment made on 3 April and alfalfa yield on 23 May was negative overall $(r=-0.35 ; \mathrm{P}=0.07)$.

At Emporia, average weevil damage on 28 March was less with spring than fall flaming, and with high- than with medium- or low-intensity flaming, with no interaction (Table 2). The high-intensity flaming treatments, both fall and spring, had less weevil damage than treatments other than the medium-intensity, spring flaming treatment and the untreated check. Conversely, the positive check, treated only with herbicide prior to assessment, had more weevil damage than all other treatments. A negative relationship existed in the positive and negative checks between weevil damage and weed density.

Weed density, primarily shepherdspurse and common chickweed [Stellaria media (L.) Vill.], was higher in all other treatments compared with the herbicide treatment (Table 2). Their density was lower in medium-intensity, spring-flamed treatments than in untreated plots, as well as in those that were fall-flamed at low and medium intensities. Average weed density was reduced in spring compared with fall flaming, with no interaction. There seemed to be confounding effects of flaming between weed density and weevil damage. The two traits were negatively correlated $(\mathrm{r}=-0.91 ; \mathrm{P}=0.01)$ in the checks, as noted previously; however, the relationship was positive $(\mathrm{r}=0.54 ; \mathrm{P}=0.02)$ when only flamed plots were included in the analysis.

\subsection{Year 2: 2012-2013}

At Mound Valley, weevil damage on 3 April, prior to chemical treatment, was greater for the checks than for all others (Table 3). The checks had more weevil damage than both the medium- and high-intensity flaming treatments in both fall and spring, with no interaction. Average weevil damage from fall and spring flaming did not differ, but flaming intensity had a clear effect, with successively less damage for each increase. 
Table 2. Effect of alfalfa treatments in 2011-2012 on subsequent weevil damage and weed density on 28 March, 2012, Fuller Farm, Emporia, KS.

\begin{tabular}{|c|c|c|c|}
\hline Timing $^{1}$ & Intensity $^{2}$ & $\begin{array}{c}\text { Weevil } \\
\text { damage }^{3}\end{array}$ & $\begin{array}{l}\text { Weed } \\
\text { density }^{4}\end{array}$ \\
\hline & & & \\
\hline \multirow[t]{3}{*}{ Fall } & Low & 3.0 & 3.7 \\
\hline & Medium & 2.7 & 4.0 \\
\hline & High & 1.3 & 3.0 \\
\hline \multirow[t]{6}{*}{ Spring } & Low & 2.3 & 3.0 \\
\hline & Medium & 1.7 & 1.8 \\
\hline & High & 1.0 & 2.3 \\
\hline & & 4.0 & 0.3 \\
\hline & No treatment & 1.3 & 3.7 \\
\hline & $\operatorname{LSD}_{(0.05)}$ & 0.8 & 1.5 \\
\hline \multicolumn{4}{|c|}{ Means, flaming treatment } \\
\hline Fall flaming & & 2.3 & 3.6 \\
\hline Spring flamin & & 1.7 & 2.4 \\
\hline \multirow[t]{5}{*}{$\operatorname{LSD}_{(0.05)}$} & & 0.5 & 1.0 \\
\hline & Low & 2.7 & 3.3 \\
\hline & Medium & 2.2 & 2.9 \\
\hline & High & 1.2 & 2.7 \\
\hline & $\operatorname{LSD}_{(0.05)}$ & 0.7 & NS \\
\hline
\end{tabular}

${ }^{1}$ Fall $=15$ November 2011; spring $=6$ March 2012. ${ }^{2}$ Intensities: low $=2.11 \mathrm{mph}$; medium = 1.25 m.p.h; high = 1.14 m.p.h. ${ }^{3}$ Visual rating: $0=$ none, 5 $=$ all leaves damaged. ${ }^{4}$ Rating: $0=$ no weeds, 5 = weed coverage over entire plot. ${ }^{5}$ Sprayed 6 March 2011 with AlfaMax.

Table 3. Effect of alfalfa treatments in 2012-2013 on subsequent weevil damage, larval counts, and forage production and dry matter content on 13 May, Steve Black Farm, Mound Valley, KS.

\begin{tabular}{|c|c|c|c|c|c|c|}
\hline \multicolumn{2}{|c|}{ Flaming treatment } & \multicolumn{2}{|c|}{ Weevil damage } & \multirow{2}{*}{$\begin{array}{l}\text { Weevil } \\
\text { larvae }\end{array}$} & \multirow{2}{*}{$\begin{array}{c}\text { Forage } \\
\text { yield }\end{array}$} & \multirow{2}{*}{$\begin{array}{c}\text { Dry } \\
\text { matter }\end{array}$} \\
\hline Timing $^{1}$ & Intensity ${ }^{2}$ & $4 / 3$ & $4 / 17$ & & & \\
\hline & & & & No./10 stems & $\mathrm{Mg} / \mathrm{ha}$ & $\%$ \\
\hline \multirow[t]{3}{*}{ Fall } & Low & 3.3 & 3.7 & 30 & 3.99 & 20.9 \\
\hline & Medium & 2.4 & 3.3 & 24 & 3.85 & 19.6 \\
\hline & High & 1.3 & 1.3 & 12 & 3.87 & 19.4 \\
\hline \multirow[t]{6}{*}{ Spring } & Low & 3.1 & 3.7 & 32 & 3.52 & 19.3 \\
\hline & Medium & 2.0 & 2.3 & 11 & 3.83 & 19.0 \\
\hline & High & 0.8 & 1.7 & 8 & 3.77 & 18.0 \\
\hline & Pesticides $^{4}$ & 4.8 & 4.3 & 2 & 3.28 & 19.2 \\
\hline & No treatment & 3.8 & 4.0 & 29 & 3.26 & 21.4 \\
\hline & $\operatorname{LSD}_{(0.05)}$ & 1.1 & 0.9 & 13 & NS & 1.7 \\
\hline \multicolumn{7}{|c|}{ Means, flaming treatment } \\
\hline Fall & & 2.3 & $2.8^{4}$ & 22 & 3.89 & 19.9 \\
\hline \multirow[t]{6}{*}{ Spring } & & 2.0 & 2.6 & 17 & 3.70 & 18.8 \\
\hline & $\operatorname{LSD}_{(0.05)}$ & NS & NS & NS & NS & 1.1 \\
\hline & Low & 3.2 & $3.7^{4}$ & 31 & 3.83 & 20.1 \\
\hline & Medium & 2.2 & 2.8 & 17 & 3.81 & 19.3 \\
\hline & High & 1.0 & 1.5 & 10 & 3.75 & 18.7 \\
\hline & $\operatorname{LSD}_{(0.05)}$ & 0.7 & 0.7 & 12 & NS & NS \\
\hline
\end{tabular}

${ }^{1}$ Fall $=29$ November 2012; spring $=27$ February 2013. ${ }^{2}$ Intensities: low $=2.18 \mathrm{mph}$; medium $=1.28 \mathrm{~m} . \mathrm{p} . \mathrm{h}$; high $=0.73$ m.p.h. ${ }^{3}$ Tons per acre at $12 \%$ forage moisture content. ${ }^{4}$ Sprayed 9 April $2013 \mathrm{w} / 5.3$ oz/a Stallion $^{\circledR}+10.3$ oz/a Lorsban ${ }^{\circledR}(=0.44 \mathrm{lb} / \mathrm{a}$ chlorpyrifos $+0.01 \mathrm{lb} / \mathrm{a}$ zeta cypermethrin $)$, plus $1.5 \mathrm{pt} / \mathrm{a}$ glyphosate + NIS. ${ }^{4}$ Time $\times$ intensity interaction; $\mathrm{P}=0.04$. 
On 17 April, weevil damage was again greater for the checks than for all other treatments except the low-intensity flaming treatments (Table 3). The checks, in turn, had more weevil damage than the high-intensity flamed treatments and the medium-intensity treatment flamed in the spring. Again, average weevil damage of fall and spring flaming did not differ, but there was a significant flaming intensity by time interaction (Figure 1). Low flaming intensities had more weevil damage than high intensities, regardless of time; however, at medium intensity, spring flaming was more effective at reducing weevil damage than fall flaming. High-intensity flaming at either time resulted in less weevil damage than medium-intensity flaming in fall.

Numbers of weevil larvae on 17 April in the negative check, the low-intensity flaming treatments for both fall and spring, and in the medium-intensity, fall-flamed treatment were greater than in the pesticide-treated and in the medium- and high-intensity spring-flamed treatments (Table 3). Average weevil larvae numbers for fall and spring flaming did not differ, but the average number of larvae in the low-intensity flaming treatment was higher than in the medium- and high-intensity flaming treatments. Numbers of weevil larvae on 17 April were lower for the pesticide treatment than for the negative check, in contrast to the amount of weevil damage in the two treatments. This result was perhaps because the alfalfa had not recovered from damage incurred prior to effects of the treatment, but overall larvae numbers were positively correlated $(r=0.70, P<0.01)$ with the extent of weevil damage on 17 April, despite the dramatic reversal of the checks.

Weed density in April at Mound Valley seemed relatively minor, so subsampling for yield and dry matter determinations at harvest replaced visual assessments. Forage yield on 13 May showed no differences among treatments (Table 3), so conditions after 17 April were apparently sufficient for alfalfa to overcome previous damage. As an indicator, dry matter content of forage was greater for the untreated check than for all treatments except for the low-intensity flame treatment. The low-intensity fall flamed treatment, in turn, had higher dry matter content than the high-intensity spring flame treatment. Average forage dry matter content was higher for fall- than spring-flamed treatments, but averages among flaming intensities did not vary significantly (Table 3). These differences could be attributed to the removal of winter annual broadleaf weeds, primarily field pepperweed [Lepidium campestre (L.) W.T. Aiton], which was relatively mature and thus had higher dry matter content than alfalfa.

At Dennis, plots were harvested for forage yield and subsampled for weed density determinations, because most weevil damage occurred after treatment and because weed infestation, primarily common chickweed, made visual assessment difficult. Total and alfalfa yields were higher in high-intensity flaming treatments than in the others (Table 4). Medium-intensity flaming treatments yielded more total forage than the check and pesticide treatments, and more alfalfa forage than the latter. Spring-timed, medium-flarned treatments also yielded more total and alfalfa forage than the check. The more intense flaming treatment provided apparently better control of chickweed than the 2,4-DB applied at the time of pesticide treatment.

Flaming alfalfa during dormancy generally provided some weevil control and reduced the number of broadleaf weeds. In the former case, removal of residue was not sufficient to reduce larval population. Low-intensity flaming, which adequately removed dried litter, did not supply sufficient heat to deter weevil infestation, as evidenced by the difference between fall and spring flaming at Emporia during a warm, open winter when egg-

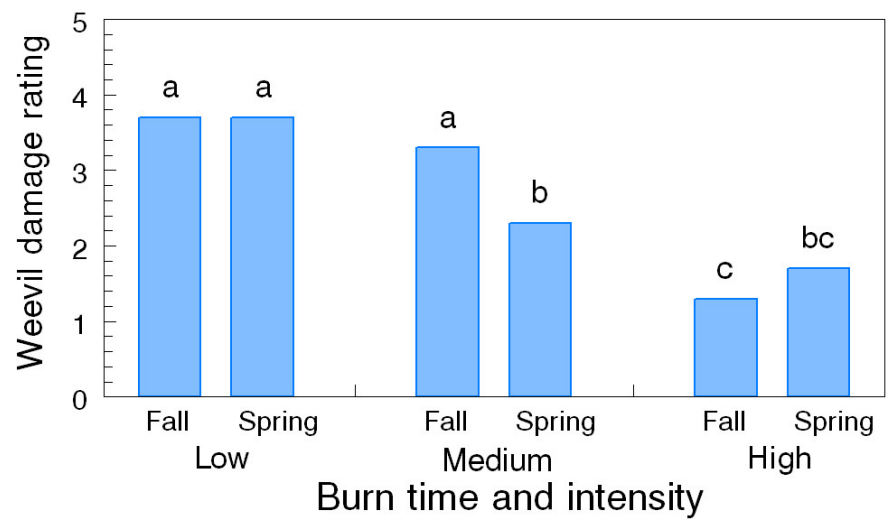

Figure 1. Alfalfa weevil damage rating on 17 April 2013 at Mound Valley as affected by the interaction of time and intensity of flaming. Bars with the same letter are not significantly $(\mathrm{P}<0.05)$ different. 
Table 4. Effect of alfalfa treatments in 2012-2013 on total forage production, and “clean” alfalfa (minus weed content) yield of the first cutting (11 May), Brad Boss Farm, Dennis, KS.

\begin{tabular}{|c|c|c|c|}
\hline \multirow[b]{2}{*}{ Timing $^{1}$} & \multirow[b]{2}{*}{ Intensity $^{2}$} & \multicolumn{2}{|c|}{ Forage yield } \\
\hline & & Total & Alfalfa $^{4}$ \\
\hline & & & \\
\hline \multirow[t]{3}{*}{ Fall } & Low & 3.62 & 0.65 \\
\hline & Medium & 3.79 & 1.13 \\
\hline & High & 4.78 & 2.25 \\
\hline \multirow[t]{6}{*}{ Spring } & Low & 3.60 & 1.15 \\
\hline & Medium & 4.09 & 1.40 \\
\hline & High & 5.06 & 2.27 \\
\hline & Pesticides $^{5}$ & 3.20 & 0.36 \\
\hline & No treatment & 3.50 & 0.43 \\
\hline & $\operatorname{LSD}_{(0.05)}$ & 0.51 & 0.63 \\
\hline \multicolumn{4}{|c|}{ Means, flaming treatment } \\
\hline Fall flaming & & 4.05 & 0.68 \\
\hline Spring flaming & & 4.25 & 0.81 \\
\hline \multirow[t]{5}{*}{$\operatorname{LSD}_{(0.05)}$} & & NS & NS \\
\hline & Low & 3.60 & 0.91 \\
\hline & Medium & 3.93 & 1.26 \\
\hline & High & 4.92 & 2.27 \\
\hline & $\operatorname{LSD}_{(0.05)}$ & 0.18 & 0.45 \\
\hline
\end{tabular}

${ }^{1}$ Fall $=29$ November 2012; spring $=27$ February 2013. ${ }^{2}$ Intensities: low $=2.18 \mathrm{mph}$; medium $=1.28 \mathrm{~m} . \mathrm{p} . \mathrm{h}$; high $=0.73$ m.p.h. ${ }^{3}$ Megagrams DM per hectare. ${ }^{4}$ Calculated by replication from concentrations in pure alfalfa and weeds (see Methods). Average DM, N, and P were 167, 37.7 and 3.9 g/kg for alfalfa, and 118, 16.9 and 4.4 for weeds. ${ }^{5}$ Sprayed 20 March 2013 with 2 qt/a Butyrac and 1.5 pt/a Poast + 0.5\% NIS, and 9 April with 2 oz/a of Baythroid.

laying could continue after fall flaming. Further investigation is needed to determine whether heat affects oviposition, egg viability, or another characteristic, and the temperature that would be required to disrupt each stage.

An economic assessment of flaming was not possible in this study, because our equipment could not provide a reliable measure of fuel usage. The amount of fuel needed to provide temperatures sufficient for control would vary, depending on burner design and orientation, and on prevailing atmospheric conditions and canopy characteristics. If benefits of insect control were combined with weed control, an efficient burner could be cost-effective for organic, and perhaps conventional, producers; however, the fact that grassy weeds are more difficult to control with flaming [13] [19] would limit the method's usefulness. The disadvantages of flaming compared with other methods, besides cost of fuel and equipment, speed of treatment, and lack of residual control [19], would be its inflexibility; that is, consistent treatment would be required in advance of any problem developing, without knowing its necessity.

\section{Acknowledgements}

Contribution No. 14-253-J of the Kansas Agricultural Experiment Station, Manhattan, KS, USA. The research was partially funded by USDA-NIFA Award No. 2010-41534-21695, Extension IPM Coordination Program for Kansas. The technical assistance of C.M. Cramer, K. R. McNickle, and L. D. Sale is appreciated. The generosity of Steve Black and Brad Boss in allowing the use of their property is also appreciated.

\section{References}

[1] Anon (2007-2012) Enterprise Summaries. Kansas Farm Management Assn. http://www.Kfma.ksu.edu

[2] USDA-NASS (2012) Crop Production Annual Summary. http://usda.mannlib.cornell.edu/MannUsda/viewDocumentInfo.do?documentID=1047

[3] Blodgett, S.L., Lenssen, A.W. and Cash, S.D. (2000) Harvest with Raking for Control of Alfalfa Weevil (Coleoptera: Curculionidae). Journal of Entomological Science, 35, 129-135. 
[4] Dellinger, T.A., Youngman, R.R., Laub, C.A., Brewster, C.C. and Kuhar, T.P. (2005) Host Effects of Glandular-Haired Alfalfa on Alfalfa Weevil (Coleoptera: Curculionidae) and Potato Leafhopper (Homoptera: Cicadellidae) Populations in Virginia. Journal of Economic Entomology, 98, 72-81. http://dx.doi.org/10.1603/0022-0493-98.1.72

[5] Tohidifar, M., Zare, N., Jouzani, G.S. and Eftekhari, S.M. (2013) Agrobacteriam-Mediated Transformation of Alfalfa (Medicago sativa) Using a Synthetic cry3a Gene to Enhance Resistance against Alfalfa Weevil. Plant Cell, Tissue and Organ Culture (PCTOC), 113, 227-235. http://dx.doi.org/10.1007/s11240-012-0262-2

[6] Guerena, M. and Sullivan, P. (2003) Organic Alfalfa Production. ATTRA Publication, Washington DC. https://attra.ncat.org/attra-pub/download.php?id=88

[7] Kuhar, T.P., Youngman, R.R. and Laub, C.A. (2000) Alfalfa Weevil (Coleoptera: Curculionadae) Population Dynamics and Mortality Factors in Virginia. Environmental Entomology, 29, 1295-1304. http://dx.doi.org/10.1603/0046-225X-29.6.1295

[8] Berberet, R.C. and Bisges, A.D. (1998) Potential for Competition among Natural Enemies of Larvae of Hypera postica (Coleoptera: Curculionidae) in the Southern Plains. Environmental Entomology, 27, 743-751.

[9] Anonymous (2012) Time to Scout for Alfalfa Weevil? Hay and Forage Grower, Minneapolis. http://hayandforage.com/alfalfa/time-scout-alfalfa-weevil

[10] Summers, C.G. (1998) Integrated Pest Management in Forage Alfalfa. Integrated Pest Management Reviews, 3, 127154. http://dx.doi.org/10.1023/A:1009654901994

[11] Catangui, M.A. (2001) Alfalfa Weevil: Evaluation of Control Practices in South Dakota. EEFS 011, Cooperative Extension Services, South Dakota State University, Brookings.

[12] Harcourt, D.G. (1981) A Thermal Summation Model for Predicting Seasonal Occurrence of the Alfalfa Weevil, Hypera postica (Coleoptera:Curculionidae), in Southern Ontario. The Canadian Entomologist, 106, 601-605. http://dx.doi.org/10.4039/Ent113601-7

[13] Moyer, J.L. and Lippert, G.E. (1996) Managing Residues of Dormant Alfalfa for Pest Control. American Forage and Grassland Council Proceedings, 5, 41-45.

[14] Dowdy, A.K., Berberet, R.C., Stritzke, R.C., Caddel, J.F. and McNew, R.W. (1992) Late Fall Harvest, Winter Grazing, and Weed Control for Reduction of Alfalfa Weevil. Journal of Economic Entomology, 85, 1946-1953.

[15] Dowdy, A.K., Berberet, R.C., Stritzke, R.C., Caddel, J.F. and McNew, R.W. (1993) Interaction of Alfalfa Weevil (Coleoptera: Curculionidae) Weeds, and Fall Harvest Options as Determinants of Alfalfa Productivity. Journal of Economic Entomology, 86, 1241-1249.

[16] Eshbaugh, E.L., Sorensen, E.L. and Moore, W.A. (1976) Two Ways to Fight Alfalfa Weevils. Keeping up with Research No. 14, Kansas Agricultural Experiment Station, Manhattan.

[17] Wynn-Williams, R.B., Rea, M.B., Purves, R.G. and Hawthorne, B.T. (1991) Influence of Winter Treading on Lucerne Growth and Survival. New Zealand Journal of Agricultural Research, 34, 271-275. http://dx.doi.org/10.1080/00288233.1991.10417664

[18] Higgins, R.A., Blodgett, S.L. and Lenssen, A.W. (1989) Alfalfa Weevil Management in Kansas: II. Non-Chemical Controls. Entomology 115, MF-918, Kansas Agricultural Research and Extension, Manhattan.

[19] Datta, A. and Knezevic, S.Z. (2013) Flaming as an Alternative Weed Control Method for Conventional and Organic Agronomic Crop Production Systems: A Review. Advances in Agronomy, 118, 399-428. http://dx.doi.org/10.1016/B978-0-12-405942-9.00006-2

[20] Knezevic, S.Z. and Ulloa, S. (2007) Potential New Tool for Weed Control in Organically Grown Agronomic Crops. Journal of Agricultural Science, 52, 95-104.

[21] Cooper, C.S., Hyder, D.N., Peterson, R.G. and Sneva, F.A. (1957) The Constituent Differential Method of Estimating Species Composition in Mixed Hay. Journal of Agricultural Science, 49, 190-193. http://dx.doi.org/10.2134/agronj1957.00021962004900040007x

[22] SAS (1990) SAS/STAT User’s Guide. Statistical Analysis System Institute, Cary. 